\title{
A Study on Sensitivities of Tropical Forest GPP Responding to the Characteristics of Drought-A Case Study in Xishuangbanna, China
}

\author{
Qian Xiong ${ }^{1} \mathbb{D}$, Zhongyi Sun ${ }^{1,2}{ }^{\mathbb{D}}$, Wei Cui ${ }^{3} \mathbb{D}$, Jizhou Lei ${ }^{1}$, Xiuxian Fu ${ }^{1}$ and Lan Wu ${ }^{1, *}$ \\ 1 College of Ecology and Environment, Hainan University, Haikou 570228, China; \\ 20071300210023@hainanu.edu.cn (Q.X.); gis.rs@hainanu.edu.cn (Z.S.); 20071300210011@hainanu.edu.cn (J.L.); \\ 20071300210006@hainanu.edu.cn (X.F.) \\ 2 Danzhou Tropical Crops Scientific Observation and Experimental Station, Ministry of Agriculture and Rural \\ Affairs, Haikou 570100, China \\ 3 Economic Development Research Center of National Forestry and Grassland Administration, \\ Ministry of Agriculture and Rural Affairs, Beijing 100000, China; cuiwei1231@hotmail.com \\ * Correspondence: wulan@hainanu.edu.cn
}

check for

updates

Citation: Xiong, Q.; Sun, Z.; Cui, W.; Lei, J.; Fu, X.; Wu, L. A Study on Sensitivities of Tropical Forest GPP Responding to the Characteristics of Drought-A Case Study in Xishuangbanna, China. Water 2022, 14, 157. https://doi.org/10.3390/ w14020157

Academic Editors: Zhenghong Tan and Ge Sun

Received: 9 November 2021

Accepted: 29 December 2021

Published: 7 January 2022

Publisher's Note: MDPI stays neutral with regard to jurisdictional claims in published maps and institutional affiliations.

Copyright: () 2022 by the authors Licensee MDPI, Basel, Switzerland. This article is an open access article distributed under the terms and conditions of the Creative Commons Attribution (CC BY) license (https:// creativecommons.org/licenses/by/ $4.0 /)$.

\begin{abstract}
Droughts that occur in tropical forests (TF) are expected to significantly impact the gross primary production (GPP) and the capacity of carbon sinks. Therefore, it is crucial to evaluate and analyze the sensitivities of TF-GPP to the characteristics of drought events for understanding global climate change. In this study, the standardized precipitation index (SPI) was used to define the drought intensity. Then, the spatially explicit individual-based dynamic global vegetation model (SEIB-DGVM) was utilized to simulate the dynamic process of GPP corresponding to multi-gradient drought scenarios-rain and dry seasons $\times 12$ level durations $\times 4$ level intensities. The results showed that drought events in the dry season have a significantly greater impact on TF-GPP than drought events in the rainy season, especially short-duration drought events. Furthermore, the impact of drought events in the rainy season is mainly manifested in long-duration droughts. Due to abundant rainfall in the rainy season, only extreme drought events caused a significant reduction in GPP, while the lack of water in the dry season caused significant impacts due to light drought. Effective precipitation and soil moisture stock in the rainy season are the most important support for the tropical forest dry season to resist extreme drought events in the study area. Further water deficit may render the tropical forest ecosystem more sensitive to drought events.
\end{abstract}

Keywords: tropical forest; gross primary production; sensitivity analysis; SEIB-DGVM; multi-gradient drought scenarios

\section{Introduction}

As the main terrestrial ecosystem, tropical forests (TF) have a higher capacity for absorbing carbon dioxide $\left(\mathrm{CO}_{2}\right)$ in the atmosphere than other forest ecosystems [1]. They play an important role in adjusting the atmospheric carbon dioxide concentration and buffering the climate of the biosphere [2,3] and are important carbon sinks [4]. However, in the past few decades, climate change has increased the severity and duration of droughts [5-7], and even the most intact and largest tropical forests have inevitably suffered from drought disturbances $[8,9]$. Studies have shown that droughts significantly affect the photosynthesis of tropical forest ecosystems [10], alter their carbon emission process [11], and affect carbon sinks [12]. Therefore, understanding the sensitivity of tropical forest gross primary productivity (TF-GPP) to drought can better predict the TF-GPP trend under future climate change scenarios, which is of great importance for mitigating climate change.

The sixth IPCC assessment report (AR6) further affirms that global warming-caused by man-made influences-has caused an increase in the frequency of extreme events and 
increased the frequency and intensity of ecological droughts [13]. In the future, precipitation in subtropical and tropical regions is expected to decrease [13], and tropical forests are highly susceptible to drought disturbances [14]. In order to improve the carbon sink capacity of tropical forests, the topic of how to reduce the impact of drought on tropical forests has become a major point of focus that is currently being faced. Existing research on drought-affected tropical forests mainly focuses on the Amazon rainforest $[8,10,12,15,16]$. The drought response of tropical forest ecosystems is analyzed by means of field observations, sample plot control experiments, and large-scale remote sensing inversion [8,17-19]. However, on-site experiments require long-term monitoring and consume a great deal of manpower and material resources [20,21]. Moreover, the tropical forest structure is highly complex, climate change amplitude is difficult to predict [22], tropical areas are covered with clouds throughout the year, and remote sensing methods are limited [23-25]. Therefore, models have become an important tool for observing and understanding the response of tropical forests to drought. Compared with Amazon and African tropical forests, tropical forests in Asia have the highest bio-carbon storage [26] and are in the Western Pacific, which is severely affected by El Niño-Southern Oscillation (ENSO) events. The tropical forests of Xishuangbanna in China are located on the northern edge of tropical southwest Asia and form part of the Malay rainforest in India. Affected by the tropical monsoon climate, precipitation presents seasonal changes, and the dry and rainy seasons are distinct. Furthermore, it is a natural site for conducting research on the response of tropical forest ecosystems to drought. The sensitivity of the TF-GPP response to multiple drought scenarios in this region is an important supplement to the global tropical forest GPP affected by drought.

The formation of drought events is extremely complex. In recent years, various drought indices have been used to evaluate different drought parameters to quantitatively analyze drought events [5]. Tropical forest ecosystems are more sensitive to moisture $[27,28]$. Compared with other drought indices such as the Palmer drought severity index (PDSI), the standardized precipitation index (SPI) is more suitable for tracking tropical forest drought events [29,30]. Different drought characteristics, e.g., drought duration and drought intensity, and the drought initiating season affect the response of vegetation to drought [1,31,32]. Fauset et al. (2012) [33] studied the effects of long-term drought on the structure and functional composition of tropical forest ecosystems. Guo et al. (2018) [34] considered time and space characteristics of drought events such as drought duration, intensity, severity, and affected areas, and assessed the impact of drought on vegetation. Furthermore, Aguirre-Gutiérrez et al. (2019) [35] found that under long-term drought, the function of different tropical forest ecosystems changes with the precipitation gradient. However, few studies have been conducted that quantify multiple drought gradients and initiating dry seasons and analyze trend changes in TF-GPP affected by multiple drought events. In addition, different ecological types, regional drought events, and GPP responses to drought under extreme drought vary [36-39]. Therefore, it is necessary to study the influence of drought on TF-GPP.

Based on the Xishuangbanna Tropical Rainforest Flux Observatory, this study simulated the dynamic response process of tropical forest ecosystem productivity under gradient scenarios with multiple drought characteristics (initiating dry season, duration, intensity) to achieve the aim of this research, that is, to reveal TF-GPP's response process to various drought features and analyze its sensitivity. The results of this study provide theoretical support for GPP changes in tropical forest ecosystems and their response to extreme events under future climate change scenarios and provide technical support for the realization of "carbon neutrality" and "nature-based solutions".

\section{Materials and Methods}

\subsection{Site Description}

The tropical forest of Xishuangbanna is located on the northern edge of tropical Southeast Asia. It is the transition zone from Southeast Asia (SE) tropical to East Asian 
subtropical. The region has a typical monsoon climate, with obvious alternations between dry (November to April) and rainy seasons (May to October) [40]. The annual average temperature is $21.5^{\circ} \mathrm{C}$ [41]; the average annual total precipitation is about $1557 \mathrm{~mm}$ [41], and about $87 \%$ [41] of the precipitation occurs in the rainy season. The study site is located in Menglun Town, Mengla County, Xishuangbanna Prefecture, Yunnan Province, Southwest China $\left(21^{\circ} 55^{\prime} 39^{\prime \prime} \mathrm{N}, 101^{\circ} 15^{\prime} 55^{\prime \prime} \mathrm{E}\right)$. It is located in tropical seasonal rain forests with a vegetation canopy height of $36 \mathrm{~m}$ [42]. The dominant tree species include Terminalia myriocarpa, Pometia tomentosa, Barringtonia macrostachya, Gironniera subaequalis, Mitrephora maingayi, Garcinia cowal, Knema erratica, Ardisia tenera, Saprosma ternatum, Pteris cretica, etc. [42,43].

\subsection{Climate Data}

Daily meteorological data required for this research include: surface temperature $\left({ }^{\circ} \mathrm{C}\right)$; $0 \sim 10 \mathrm{~cm}, 10 \sim 200 \mathrm{~cm}$, and $300 \mathrm{~cm}$ deep soil temperature $\left({ }^{\circ} \mathrm{C}\right)$; precipitation $(\mathrm{mm})$; cloud coverage (fraction); and specific humidity $(\mathrm{kg} / \mathrm{kg})$. These data were obtained by using the National Center for Environmental Prediction/National Center for Atmospheric Research (NCEP/NCAR) data [44] set to calibrate the monthly CRU-Ts4.05 meteorological data [45] set (1981-2019) on a daily scale. Among them, abnormal precipitation values are replaced by meteorological daily value data of the Xishuangbanna Station from 2003 to 2010 of the National Ecological Science Data Center (NESDC). The daily temperature difference $\left({ }^{\circ} \mathrm{C}\right)$ is CRU monthly data, consistent within the month; canopy wind speed (m/s) uses NCEP/NCAR reanalysis data; GPP observation value is NESDC 2003-2010 Xishuangbanna station flux monthly data.

\subsection{Method}

\subsubsection{SPI}

The standardized precipitation index uses the long-term precipitation distribution in a certain area to assess the degree of drought in that area. Generally, monthly-scale precipitation series are used as the research object, and the cumulative probability distribution of precipitation is calculated and then normalized to obtain the standardized precipitation index [46]. If the precipitation in a certain area is greater than the historical average precipitation, the SPI value of the area is positive; conversely, a negative SPI value means that the precipitation in the area is less than the historical average precipitation [47]. According to the SPI value, different drought levels can be divided. In this study, SPI was used to calculate the precipitation change in multiple drought scenarios from 1981 to 2019 , and four drought intensities were distinguished according to the magnitude of the SPI value.

\subsubsection{SEIB-DGVM}

SEIB-DGVM dynamically simulates the establishment, growth, competition, and death stages of various vegetations. It is driven by geographic and meteorological data to simulate terrestrial physical processes, vegetation physiological processes, and vegetation dynamic processes, which can accurately assess the response of terrestrial ecosystems to climate change. SEIB-DGVM can simulate the sensitivity of ecosystem photosynthesis to precipitation frequency, intensity, and rainy season length [48], which is beneficial for reflecting the sensitivity of GPP to drought intensity, duration, and initial dry season. The model contains 16 plant function types (PFTs). In this study, four tropical broad-leaved evergreen forests (PFT1: shade-tolerant species with a maximum tree height greater than $36 \mathrm{~m}$; PFT2: shade-tolerant species with a maximum tree height of 25-36 m; PFT3: light-demanding species with a maximum tree height of 15-25 m; PFT4: intermediate shade-tolerant species with a maximum tree height of $1.3-15 \mathrm{~m}$ ) were launched for simulation $[49,50]$.

In this study, meteorological data from 1981 to 2010 were used for 300 years of spinup to ensure that the ecosystem was in balance. Daily standard weather from 1981 to 2019 was used to repeatedly simulate 100-year changes in the Xishuangbanna ecosystem 
GPP affected by multiple droughts (Figure 1). The model version is SEIB-DGVM 2.82 (This version corresponds with Sato et al. 2015) [51].

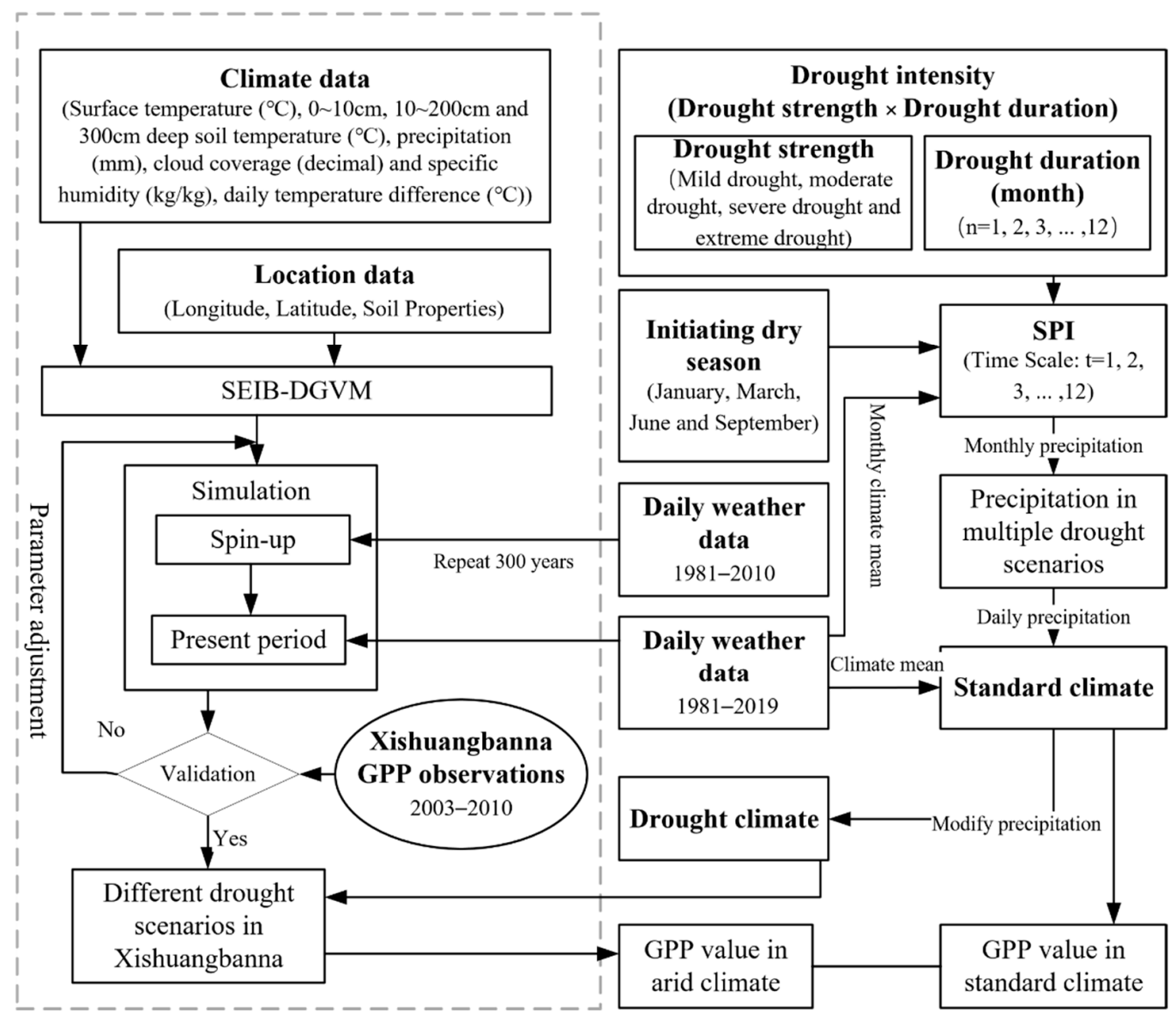

Figure 1. Model running and experiment process.

\subsubsection{Adaptation of SEIB-DGVM}

Our research verifies the adaptation of SEIB-DGVM based on the GPP monthly flux data of the NESDC Xishuangbanna station from 2003 to 2010. The diameter limits (DBH_limit) of the four PFTs are $0.71 \mathrm{~m}, 0.58 \mathrm{~m}, 0.45 \mathrm{~m}$, and $0.11 \mathrm{~m} \mathrm{[52],} \mathrm{and} \mathrm{the}$ maximum tree height (HGT_max) is set to $55 \mathrm{~m}, 55 \mathrm{~m}, 54 \mathrm{~m}$, and $40 \mathrm{~m}$ [53]; the optimum temperature (Topt) is adjusted to $20^{\circ} \mathrm{C}$; the maximum photosynthetic rate (Pmax) of PFT1 and PFT3 were adjusted to 5.5 and 10.5, respectively; and the light use efficiency (Lue0) of the four PFTs was adjusted to 0.047 [54].

\subsubsection{Experiment Design for Multiple Drought Scenarios}

Daily meteorological data from 1981 to 2019 were selected to calculate the daily standard climate state of Xishuangbanna, which is used to simulate the GPP value (GPP_Sta) under the standard climate of the tropical rainforest ecosystem in Xishuangbanna. Different SPI time scales (SPI_1, SPI_2, SPI_3, SPI_4, SPI_5, SPI_6, SPI_7, SPI_8, SPI_9, SPI_10, SPI_11, and SPI_12) were used to calculate precipitation in multiple drought scenarios. For example, SPI_1 refers to the SPI value on a one-month time scale, representing the distribution of precipitation in the current month; SPI_3 refers to the SPI value on a three-month time scale, representing the cumulative precipitation change from the previous two months to the current month. The initiating dry season, drought duration, and drought intensity were determined to simulate multiple drought scenarios (Figure 2). In this study, the initiating dry seasons are January (cool-dry season, CD), March (hot-dry season, HD), June (early rainy season, ER), and September (mid-to-late rainy season, MLR); drought 
duration is $12,11,10,9,8,7,6,5,4,3,2$, and 1 months; drought intensity is light drought $(\mathrm{SPI}=-0.75)$, moderate drought (SPI $=-1.25)$, severe drought (SPI $=-1.75)$, and extreme drought (SPI $=-2.00$ ). There was a total of 23,040 simulations in this study (4 seasons $\times 12$ duration $\times 4$ intensity $\times 12$ SPI time scale $\times 10$ repetitions). The results of the GPP simulation (GPP_Mod) and GPP_Sta in each drought scenario were compared and analyzed, and the impact of drought on GPP was evaluated.

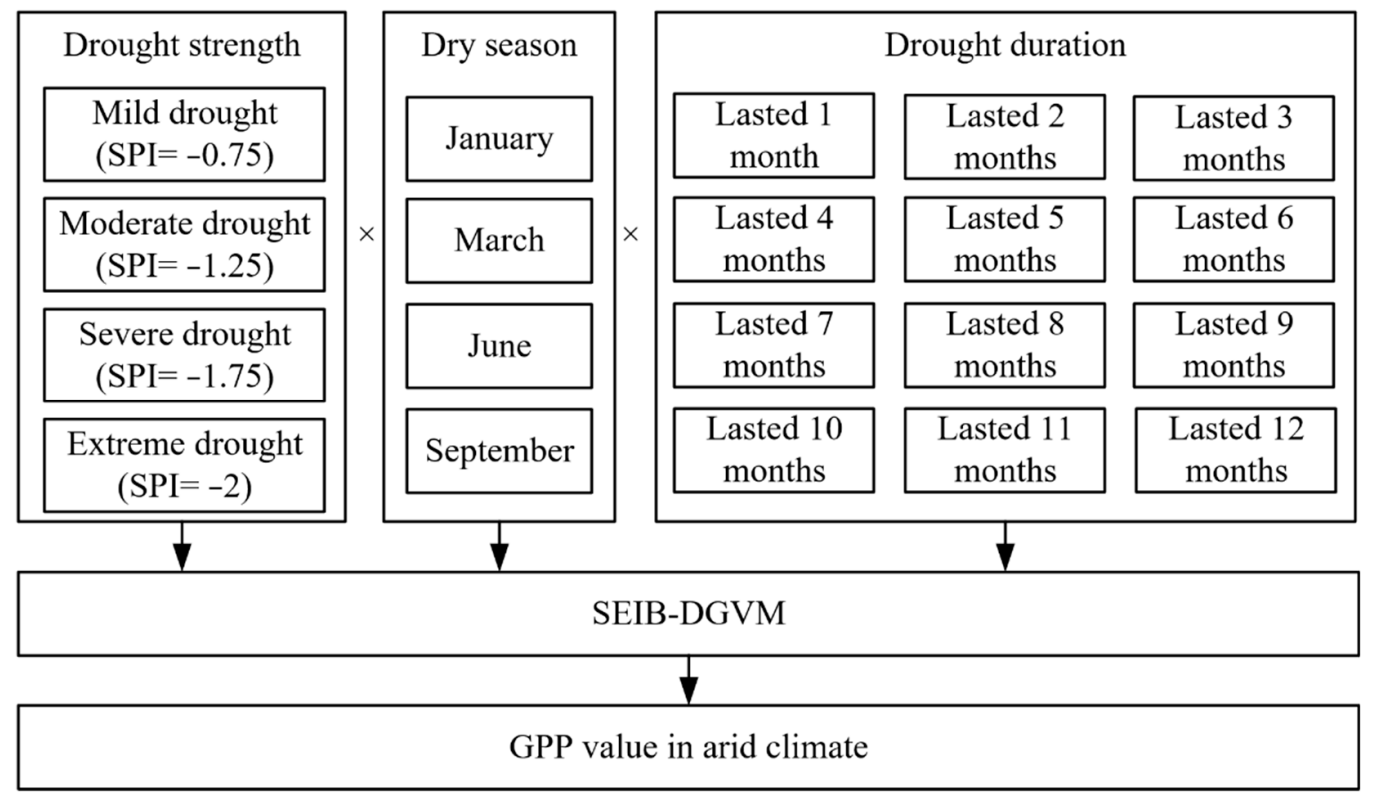

Figure 2. Multi-drought scenario design.

\section{Results}

\subsection{Model Validation}

Figure 3a shows the estimated monthly GPP value (GPP_Est) for this study and the monthly GPP value (GPP_Obs) time series of the NESDC Xishuangbanna station monthly flux value data from 2003 to 2010. Figure 3b shows the scatter point of GPP_Est and GPP_Obs. The overall trend of the monthly GPP value of the model fits well $\left(\mathrm{R}^{2}=0.56\right)$; the correlation coefficient $(\mathrm{R}=0.85)$ between GPP_Est and GPP_Obs is relatively high; the root mean square error (RMSE) is $38.13 \mathrm{~g} \mathrm{C} \mathrm{m}^{-2} \mathrm{month}^{-1}$; the average relative error (RE) is $12.04 \%$. SEIB-DGVM can effectively reproduce the monthly-scale GPP dynamic pattern of the tropical rain forest flux observation station in Xishuangbanna, which can be used for GPP estimation under multiple drought scenarios.
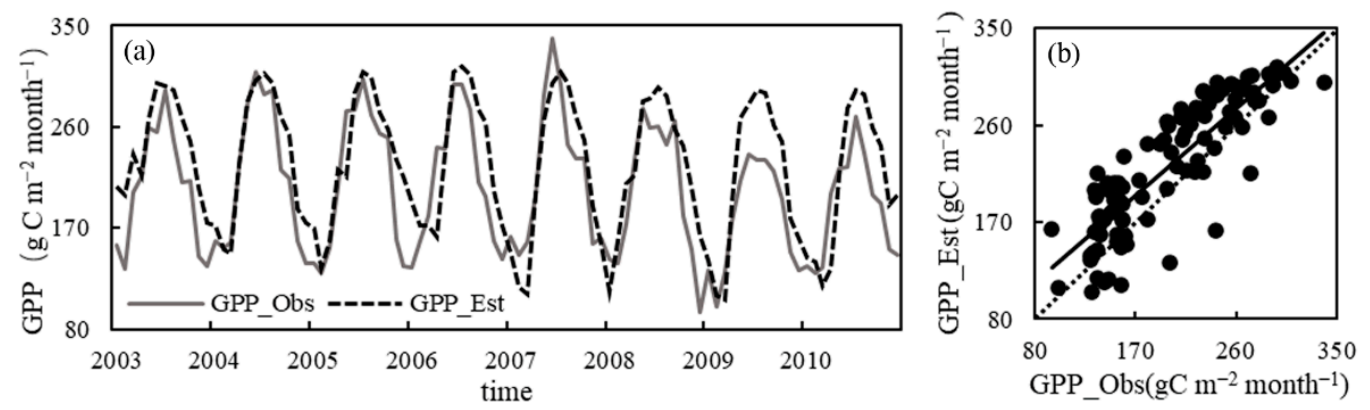

Figure 3. (a) Timeseries of GPP_Est and GPP_Obs from 2003 to 2010; (b) scatter plot of GPP_Est and GPP_Obs from 2003 to 2010. 


\subsection{The Sensitivities of TF-GPP to Droughts Occurring Different Seasons}

Figure 4 shows the GPP loss caused by drought in different seasons. Under the same drought duration and intensity, the $\triangle \mathrm{GPP}\left(\triangle \mathrm{GPP}=\mathrm{GPP} \_\right.$Sta - GPP_Mod $)$change in HD is the most significant, and the $\triangle \mathrm{GPP}$ change in ER is the least significant. The GPP change in drought initiated in the dry season is more significant than drought initiated in the rainy season.

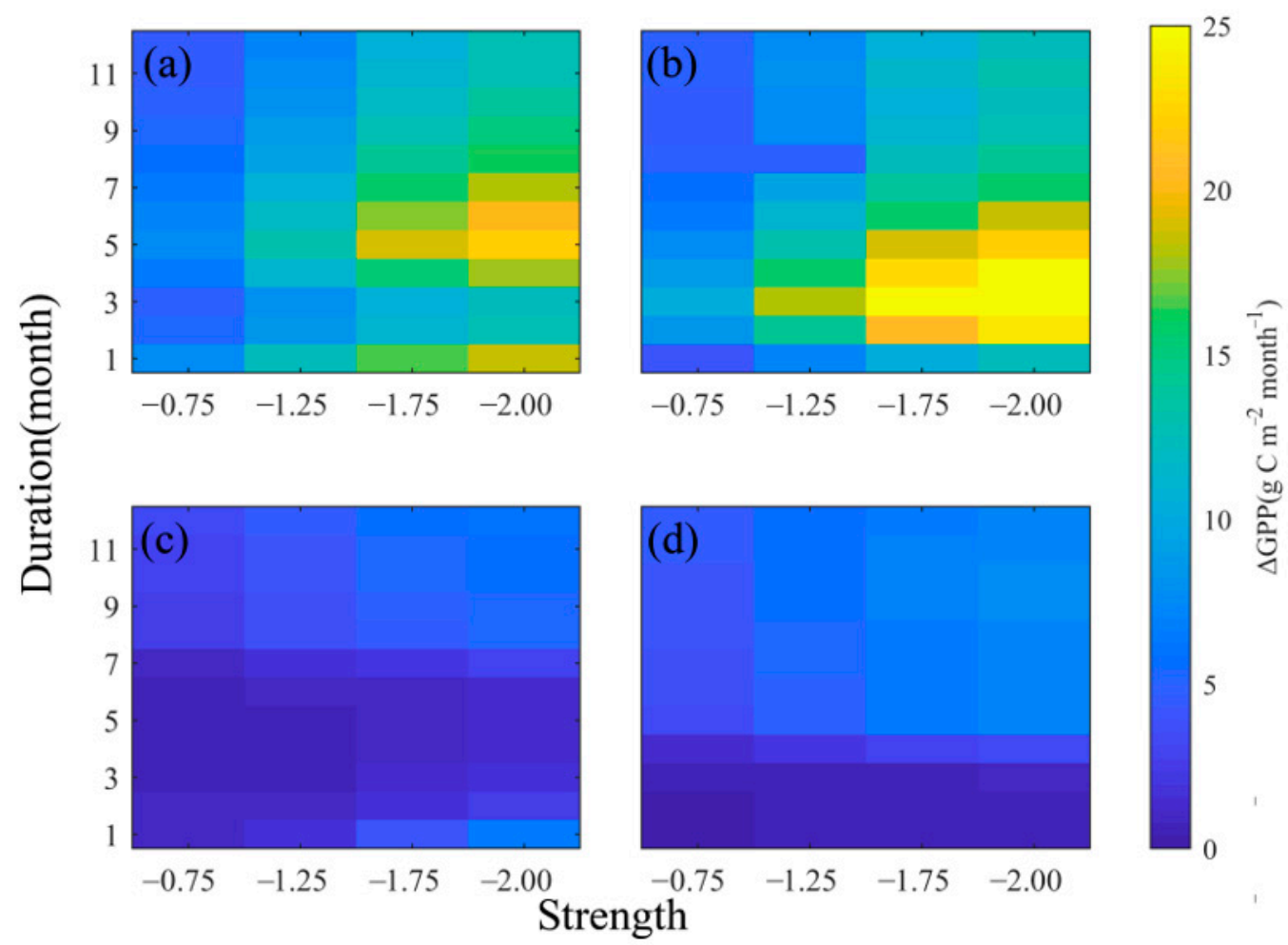

Figure 4. Under SPI_9 (a) CD; (b) HD; (c) ER and (d) MLR initiate drought, the difference between the average monthly GPP in standard climate and the average GPP in arid climate month $\left(\triangle \mathrm{GPP}=\mathrm{GPP} \_\right.$Sta - GPP_Mod) varies with the duration and strengths of the drought.

Drought initiation during the dry season. The GPP impairment value is more affected by drought intensity than drought duration. As drought intensity increases, $\triangle G P P$ also increases. When drought duration increases, $\triangle \mathrm{GPP}$ first increases and then decreases. Drought occurs in the CD, and GPP loss reaches the maximum $\left(22.09 \mathrm{~g} \mathrm{C} \mathrm{m}^{-2} \mathrm{month}^{-1}\right)$ after 5 months of continuous drought (Figure S1a). Drought occurs in the MD, and $\triangle G P P$ reaches the maximum ( $31.31 \mathrm{~g} \mathrm{C} \mathrm{m}^{-2}$ month $^{-1}$ ) after 3 months of continuous drought (Figure S1b).

Drought initiation during the rainy season. Drought duration has a more obvious impact on GPP than intensity, and $\triangle$ GPP increases with the increase in drought intensity. Drought started in ER: $\triangle$ GPP first decreases and then increases with the increase in drought duration. The turning point occurred when drought lasted 5 months. At this time, the $\triangle \mathrm{GPP}$ was $0.64 \mathrm{~g} \mathrm{C} \mathrm{m}^{-2}$ month $^{-1}, 0.77 \mathrm{~g} \mathrm{C} \mathrm{m}^{-2}$ month $^{-1}, 0.94 \mathrm{~g} \mathrm{C} \mathrm{m}^{-2}$ month $^{-1}$, and $1.23 \mathrm{~g} \mathrm{C} \mathrm{m}^{-2} \mathrm{month}^{-1}$ as drought intensity increased. (Figure S1c). When the drought lasted for 8 months or more, $\triangle$ GPP increased significantly (Figure S1c), and the $\triangle$ GPP was $2.49 \mathrm{~g} \mathrm{C} \mathrm{m}^{-2}$ month $^{-1}, 3.52 \mathrm{~g} \mathrm{C} \mathrm{m}^{-2} \mathrm{month}^{-1}, 4.68 \mathrm{~g} \mathrm{C} \mathrm{m}^{-2} \mathrm{month}^{-1}$, and $5.25 \mathrm{~g} \mathrm{C} \mathrm{m}^{-2} \mathrm{month}^{-1}$ as the drought intensity increased. Drought occurred in MLR, and $\triangle$ GPP first increased with the increase in drought duration and then almost remained unchanged (Figure 4). The drought lasted more than 4 months, and GPP decreased significantly, and its values were $1.33 \mathrm{~g} \mathrm{C} \mathrm{m}^{-2}$ month $^{-1}$, $2.11 \mathrm{~g} \mathrm{C} \mathrm{m}^{-2}$ month $^{-1}$, $2.92 \mathrm{~g} \mathrm{C} \mathrm{m}^{-2} \mathrm{month}^{-1}$, and $3.38 \mathrm{~g} \mathrm{C} \mathrm{m}^{-2}$ month $^{-1}$ as the intensity increased (Figure S1d). 
The sensitivities of TF-GPP to droughts occurring different seasons under SPI_1,SPI_3, SPI_6 and SPI_12 time scales are shown in Figures S2-S5.

\subsection{The Sensitivities of TF-GPP to Drought Duration}

Figure 5 shows the GPP losses due to different drought durations under the gradient of drought seasons and strengths. Keep the drought intensity consistent with the initial dry season. Short-duration drought has a more obvious impact on GPP in the dry season than in the rainy season, and the difference in $\triangle$ GPP between the two dry and rainy seasons is significant; the GPP in the rainy season changes significantly in the long-duration drought, and GPP is almost unaffected in the dry season.
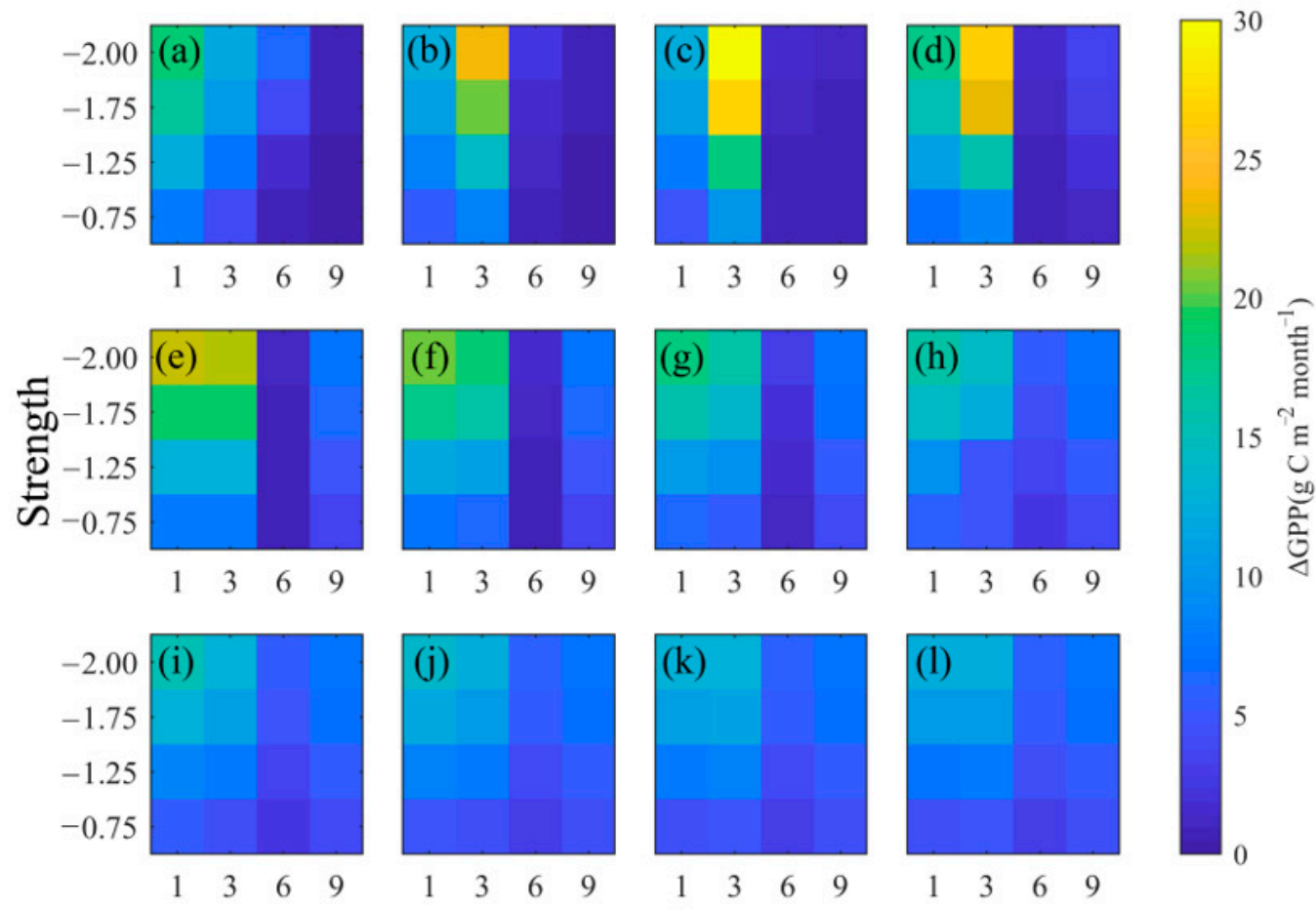

month

Figure 5. Drought duration under SPI_9: (a) 1 month; (b) 2 months; (c) 3 months; (d) 4 months; (e) 5 months; (f) 6 months; (g) 7 months; (h) 8 months; (i) 9 months; (j) 10 months; (k) 11 months; and

(l) 12 months. $\triangle$ GPP varies with drought intensity and initial drought seasonal changes.

Under short-duration drought (drought duration is less than 5 months), GPP loss due to drought in the rainy season is not obvious and hardly changes with the change in drought intensity (Figure 5a,b). When a drought event occurs in the dry season, $\triangle \mathrm{GPP}$ changes significantly and increases with increasing intensity (Figure 5a-e).

Under long-duration drought (drought duration is greater than 7 months), GPP loss in the rainy season begins to increase with the increase in drought intensity. When the drought lasted for 7 months and the drought started in ER, $\triangle$ GPP started changing significantly with the increase in drought intensity- $1.17 \mathrm{~g} \mathrm{C} \mathrm{m}^{-2}$ month $^{-1}, 1.68 \mathrm{~g} \mathrm{C} \mathrm{m}^{-2} \mathrm{month}^{-1}$, $2.21 \mathrm{~g} \mathrm{C} \mathrm{m}^{-2}$ month $^{-1}$, and $2.86 \mathrm{~g} \mathrm{C} \mathrm{m}^{-2}$ month $^{-1}$. GPP loss in the dry season is almost unaffected by changes in drought duration (Figure $5 \mathrm{~g}-1$ ); moreover, drought lasted more than 4 months when the drought started in MLR, and $\triangle$ GPP increased with the increase in duration and intensity (Figure 5d-1).

The sensitivities of TF-GPP to drought duration under SPI_1, SPI_3, SPI_6 and SPI_12 time scales are shown in Figures S6-S9. 


\subsection{The Sensitivities of TF-GPP to Drought Strengths}

Figure 6 shows the GPP losses due to different drought strengths under the gradient of drought seasons and durations. With the increase in drought intensity, the GPP loss of drought in the dry season increased significantly, and the $\triangle$ GPP in the rainy season increased slightly. Furthermore, when the drought duration is consistent with the initial dry season, the impact of drought intensity on $\triangle \mathrm{GPP}$ in the dry season is more pronounced than in the rainy season.

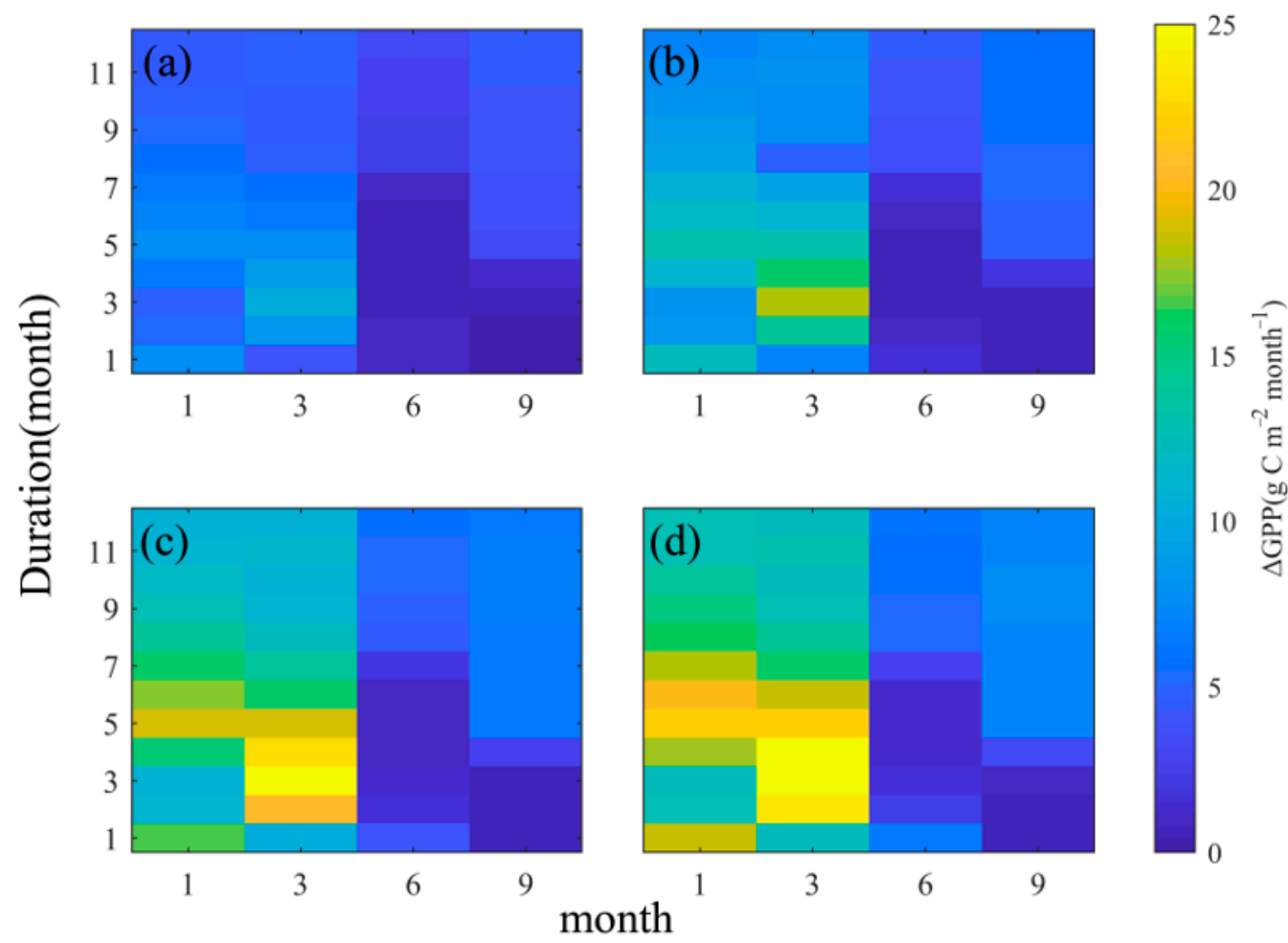

Figure 6. Drought intensity under SPI_9 is (a) light drought; (b) moderate drought; (c) severe drought; and (d) extreme drought. $\triangle$ GPP varies with the duration of the drought and the initial drought season.

Under mild drought intensity, GPP will not reduce significantly regardless of whether there is a drought in the dry season or the rainy season; however, when a drought occurs in the rainy season, $\triangle \mathrm{GPP}$ will increase with the increase in duration (Figure 6a). Drought started in $C D$, and $\triangle G P P$ first decreased and then increased with the increase in duration. Drought started in HD, and $\triangle \mathrm{GPP}$ first increased and then decreased with the increase in duration.

Under moderate drought intensity, the dry season $\triangle \mathrm{GPP}$ began to change significantly; when the drought lasted 8 months and began in HD, $\triangle$ GPP had a minimum value of $4.997 \mathrm{~g} \mathrm{C} \mathrm{m}^{-2}$ month $^{-1}$ (Figure $6 \mathrm{~b}$ ).

Under severe drought and extreme drought intensity, drought occurs during the dry season, and its GPP changes significantly (Figure 6c,d). Under extreme drought intensity, changes in $\triangle$ GPP are the most significant. With the different seasons $(C D, H D, E R$, and MLR), when drought begins, the maximum values are also different: $22.09 \mathrm{~g} \mathrm{C} \mathrm{m}^{-2} \mathrm{month}^{-1}$, $31.31 \mathrm{~g} \mathrm{C} \mathrm{m}^{-2}$ month $^{-1}, 6.448 \mathrm{~g} \mathrm{C} \mathrm{m}^{-2}$ month $^{-1}$, and $7.468 \mathrm{~g} \mathrm{C} \mathrm{m}^{-2} \mathrm{month}^{-1}$.

The sensitivities of TF-GPP to drought strengths under SPI_1, SPI_3, SPI_6 and SPI_12 time scales are shown in Figures S10-S13.

\section{Discussion}

\subsection{Drought Initiation Season}

Drought occurs during the rainy season, and GPP loss is not significant. This is because the rainfall in the rainy season-in the study area-is significantly higher than the 
water demand of the vegetation. When rainfall from the rainy season decreases in a short period of time, vegetation is still able to use part of the precipitation to maintain its growth and survival processes and will not suffer obvious water stress. At this time, the primary productivity of the ecosystem is fairly sensitive to drought events. With the development of drought events (drought lasting more than 4 months), the lack of long-term precipitation caused water shortages to restrict vegetation growth, which caused a significant decline in GPP during the rainy season. The rainfall in the tropical rainforest ecosystem of Xishuangbanna in June was significantly higher than that recorded in September $[55,56]$. Maintaining consistent drought duration and drought intensity, the ER ecosystem has more water resources that are needed to maintain the growth and survival of vegetation and possesses stronger resistance to drought events. Therefore, drought occurs at ER, and the loss of ecosystem GPP is the least significant. Droughts began in CD and HD, and ecosystem productivity dropped significantly. This is due to the dry season in Xishuangbanna from November to April of the following year. During this period, the ecosystem has minimal or no precipitation $[57,58]$, and vegetation often suffers from severe water stress $[59,60]$. In order to maintain its own growth, it is necessary to continuously expand the roots deep into the soil to obtain soil moisture [61-63]. Soil moisture can adequately buffer the impact of seasonal drought on vegetation [64], and its distribution and utilization greatly affect the growth and survival of vegetation [65]. At the beginning of the dry season, the ecosystem experiences heavy rainfall during the rainy season, and soil moisture is adequately stored. The ecosystem is able to adjust to short-duration droughts. Therefore, the GPP of the drought-initiated ecosystem in the early dry season does not decline drastically. After a long period of drought, the ecosystem has almost no precipitation [58]. At this time, vegetation is more dependent on soil moisture. Due to the inability to replenish soil moisture in the dry season, the ecosystem's water resources become further deficient. With the development of drought events (lasting more than 3 months), vegetation water consumption exceeds soil water reserves, and vegetation productivity begins to significantly decline. Li et al. (2010) [57] indicated that the highest temperature of the tropical forest ecosystem in Xishuangbanna was from March to April instead of from June to July. Drought occurred during this period, and the temperature increased and vegetation died. This further explains that drought in HD has a more significant reduction in productivity than drought in CD.

\subsection{Drought Duration}

Vicente-Serrano et al. (2013) [66] stated that vegetation responds quickly to short-term water deficits below normal levels. Therefore, when drought occurs in the dry season, the primary productivity of the ecosystem will decrease significantly in the short term. With the development of drought events, vegetation quickly adapts to the ever-changing available water resources [66], controls water consumption, increases roots' absorption of soil water [67], and buffers drought pressure, and the loss of ecosystem productivity tends to gradually flatten. Drought occurs at the CD, and $\triangle$ GPP begins to decrease after the drought lasts more than 5 months. In addition, when drought occurs in the HD, $\triangle \mathrm{GPP}$ also decreases after the drought lasts more than 3 months. This is because, at this time, the ecosystem enters the rainy season, and the precipitation increases significantly compared to previously. In the rainy season ecosystem, under a short-duration drought, vegetation can obtain deep soil water to relieve water stress [68], meaning that the primary productivity of the ecosystem will not change significantly. Long-term drought will cause vegetation leaves to fall away $[69,70]$, and deep soil water or even bedrock water will become depleted [71], causing tree death. Furthermore, long-term precipitation reduction reaches a threshold, which may lead to the conversion of tropical forest ecosystems to other ecosystems [63], thereby significantly reducing ecosystem productivity. Vegetation in the dry season is more severely affected by water stress, and the soil moisture content is less than that in the rainy season. Therefore, the GPP in the dry season is more degraded under a shorter drought duration than in the rainy season. 


\subsection{Drought Strengths}

Under mild to moderate drought, the response of trees to drought is a gradual process. At this time, trees activate physiological regulation processes to alleviate the effects of drought events by increasing carbon storage in their organs [72], thus, the TF-GPP did not change significantly under mild and moderate drought. Drought not only affects vegetation growth but also increases the risk of pests and diseases, significantly reduces canopy photosynthesis [73], and inhibits the primary productivity of the ecosystem. In addition, severe drought can also disrupt the hydraulic balance of vegetation and limit vegetation growth and the synthesis of structural substances, resulting in a net loss of carbohydrates [72,74]. Moreover, soil moisture storage is gradually depleted, leading to vegetation death due to severe water shortages before carbon depletion, which has an irreversible impact on the ecosystem in the short term $[75,76]$, resulting in a significant decrease in primary productivity of the ecosystem. As rainfall in the rainy season ecosystem is higher than the vegetation water demand, soil moisture is adequately stored, and vegetation is limited by water (less so than the dry season ecosystem). Moreover, with the increase in drought intensity, GPP loss in the rainy season is significantly less than that of the dry season ecosystem.

\section{Conclusions}

This study shows that the increase in drought duration and drought intensity significantly affects the productivity of tropical forest ecosystems, and the response of tropical forests to drought in different initiating dry seasons is also significantly different. TF-GPP in the dry season is more affected by drought than in the rainy season. Ecosystem productivity in the dry season is sensitive to short-duration and high-intensity drought events; when drought lasts for 3 months when the intensity reaches a moderate drought, GPP begins to decrease significantly. For droughts lasting more than 5 months in the rainy season, the ecosystem productivity decreases significantly, and GPP does not change significantly with intensity. The impact of short-duration drought events on the TF-GPP in the dry season is more obvious than that in the rainy season. Long-duration drought events cause no significant difference in GPP loss caused by the dry and rainy seasons.

Drought formation conditions are complex, which not only affect precipitation changes but also affect the potential evapotranspiration of vegetation and raise the temperature. This study only considered changes in precipitation and did not consider the coupling between high temperature and lack of water, which will be the focus of future research.

Supplementary Materials: The following are available online at https: / www.mdpi.com/article / 10.3390/w14020157/s1, Figure S1: Under SPI_9 (a) CD; (b) HD; (c) ER and (d) MLR initiate drought, the difference between the average monthly GPP in standard climate and the average GPP in arid climate month $\left(\triangle \mathrm{GPP}=\mathrm{GPP} \_\right.$Sta - GPP_Mod) varies with the duration and strengths of the drought. Figure S2: Under SPI_1 (a) CD; (b) HD; (c) ER and (d) MLR initiate drought, the $\triangle$ GPP varies with the duration and strengths of the drought. Figure S3: Under SPI_3 (a) CD; (b) HD; (c) ER and (d) MLR initiate drought, the $\triangle \mathrm{GPP}$ varies with the duration and strengths of the drought. Figure S4: Under SPI_6 (a) CD; (b) HD; (c) ER and (d) MLR initiate drought, the $\triangle$ GPP varies with the duration and strengths of the drought. Figure S5: Under SPI_12 (a) CD; (b) HD; (c) ER and (d) MLR initiate drought, the $\triangle \mathrm{GPP}$ varies with the duration and strengths of the drought. Figure S6: Drought duration under SPI_1 (a) 1 month; (b) 2 months; (c) 3 months; (d) 4 months; (e) 5 months; (f) 6 months; (g) 7 months; (h) 8 months; (i) 9 months; (j) 10 months; (k) 11 months and (1) 12 months, $\Delta$ GPP varies with drought intensity and initial drought seasonal changes. Figure S7: Drought duration under SPI_3 (a) 1 month; (b) 2 months; (c) 3 months; (d) 4 months; (e) 5 months; (f) 6 months; (g) 7 months; (h) 8 months; (i) 9 months; (j) 10 months; (k) 11 months and (1) 12 months, $\Delta$ GPP varies with drought intensity and initial drought seasonal changes. Figure S8: Drought duration under SPI_6 (a) 1 month; (b) 2 months; (c) 3 months; (d) 4 months; (e) 5 months; (f) 6 months; (g) 7 months; (h) 8 months; (i) 9 months; (j) 10 months; (k) 11 months and (1) 12 months, $\triangle$ GPP varies with drought intensity and initial drought seasonal changes. Figure S9: Drought duration under SPI_12 (a) 1 month; (b) 2 months; (c) 3 months; (d) 4 months; (e) 5 months; (f) 6 months; (g) 7 months; (h) 8 months; 
(i) 9 months; (j) 10 months; (k) 11 months and (1) 12 months, $\triangle$ GPP varies with drought intensity and initial drought seasonal changes. Figure S10: The drought intensity under SPI_1 is (a) light drought; (b) moderate drought; (c) severe drought and (d) extreme drought, $\triangle$ GPP varies with the duration of the drought and the initial drought season. Figure S11: The drought intensity under SPI_3 is (a) light drought; (b) moderate drought; (c) severe drought and (d) extreme drought, $\triangle$ GPP varies with the duration of the drought and the initial drought season. Figure S12: The drought intensity under SPI_6 is (a) light drought; (b) moderate drought; (c) severe drought and (d) extreme drought, $\triangle \mathrm{GPP}$ varies with the duration of the drought and the initial drought season. Figure S13: The drought intensity under SPI_12 is (a) light drought; (b) moderate drought; (c) severe drought and (d) extreme drought, $\triangle \mathrm{GPP}$ varies with the duration of the drought and the initial drought season.

Author Contributions: Conceptualization, Q.X., Z.S. and L.W.; methodology, Q.X., Z.S., W.C., J.L., X.F. and L.W.; software, Q.X. and Z.S.; validation, Q.X.; formal analysis, Q.X., Z.S. and L.W.; investigation, Q.X., Z.S., W.C., J.L., X.F. and L.W.; resources, Q.X. and Z.S.; data curation, Q.X. and Z.S.; writingoriginal draft preparation, Q.X.; writing-review and editing, Q.X., Z.S., W.C., J.L., X.F. and L.W.; visualization, Q.X.; supervision, J.L., X.F. and L.W.; project administration, L.W.; funding acquisition, Z.S. and W.C. All authors have read and agreed to the published version of the manuscript.

Funding: This research was funded by (1) Youth Foundation of the Natural Science Foundation of Hainan Province of China, grant number 320QN202; (2) Fund for Less Developed Regions of the National Natural Science Foundation of China, grant number 32160320; (3) Youth Foundation of the National Natural Science Foundation of China, grant number 42101101.

Institutional Review Board Statement: Not applicable.

Informed Consent Statement: Not applicable.

Data Availability Statement: Xishuangbanna GPP observations dataset is provided by National Ecosystem Science Data Center, National Science \& Technology Infrastructure of China. This data can be found here: http:/ / www.nesdc.org.cn (accessed on 27 December 2021). Surface temperature, $0 \sim 10 \mathrm{~cm}, 10 \sim 200 \mathrm{~cm}$ and $300 \mathrm{~cm}$ deep soil temperature, precipitation, cloud coverage and specific humidity data sets are provided by CRU-Ts 4.05 , and NCEP/NCAR is used to supplement daily values. The daily temperature difference is provided by CRU monthly data; canopy wind speed is provided by NCEP/NCAR reanalysis data. CRU monthly data can be found here: https:/ / crudata. uea.ac.uk/cru/data/hrg/cru_ts_4.05/(accessed on 27 December 2021). NCEP/NCAR reanalysis data can be found here: https://psl.noaa.gov/data/index.html (accessed on 27 December 2021). The data presented in this study are available on request from the corresponding author.

Acknowledgments: The authors acknowledge the staff of the Xishuangbanna Tropical Rainforest Flux Observation Site for their support to the flux tower data. The authors acknowledge the National Ecosystem Science Data Center, National Science \& Technology Infrastructure of China for providing flux site data support. The authors thank Climatic Research Unit (University of East Anglia) and Met Office for providing monthly meteorological data sets, and also thank National Oceanic and Atmospheric Administration Physical Sciences Laboratory for providing reanalysis data, which can provide daily supplements to monthly meteorological data. The authors would like to thank all colleagues and students who contributed to this study. In addition, the authors also thank each fund project for providing support for this research.

Conflicts of Interest: The authors declare no conflict of interest.

\section{References}

1. Corlett, R.T. The Impacts of Droughts in Tropical Forests. Trends Plant Sci. 2016, 21, 584-593. [CrossRef]

2. Hubau, W.; Lewis, S.L.; Phillips, O.L.; Affum-Baffoe, K.; Beeckman, H.; Cuni-Sanchez, A.; Daniels, A.K.; Ewango, C.E.N.; Fauset, S.; Mukinzi, J.M.; et al. Asynchronous carbon sink saturation in African and Amazonian tropical forests. Nature 2020, 579 , 80-87. [CrossRef]

3. Xu, C.; McDowell, N.G.; Fisher, R.A.; Wei, L.; Sevanto, S.; Christoffersen, B.O.; Weng, E.; Middleton, R.S. Increasing impacts of extreme droughts on vegetation productivity under climate change. Nat. Clim. Change 2019, 9, 948-953. [CrossRef]

4. Soepadmo, E. Tropical rain forests as carbon sinks. Chemosphere 1993, 27, 1025-1039. [CrossRef]

5. Mukherjee, S.; Mishra, A.; Trenberth, K.E. Climate change and drought: A perspective on drought indices. Curr. Clim. Change Rep. 2018, 4, 145-163. [CrossRef] 
6. Cook, B.I.; Mankin, J.S.; Anchukaitis, K.J. Climate change and drought: From past to future. Curr. Clim. Change Rep. 2018, 4, 164-179. [CrossRef]

7. Cook, B.I.; Smerdon, J.E.; Seager, R.; Coats, S. Global warming and 21st century drying. Clim. Dyn. 2014, 43, 2607-2627. [CrossRef]

8. Phillips, O.L.; Aragão, L.E.; Lewis, S.L.; Fisher, J.B.; Lloyd, J.; López-González, G.; Malhi, Y.; Monteagudo, A.; Peacock, J.; Quesada, C.A. Drought sensitivity of the Amazon rainforest. Science 2009, 323, 1344-1347. [CrossRef]

9. Sitch, S.; Huntingford, C.; Gedney, N.; Levy, P.; Lomas, M.; Piao, S.; Betts, R.; Ciais, P.; Cox, P.; Friedlingstein, P.; et al. Evaluation of the terrestrial carbon cycle, future plant geography and climate-carbon cycle feedbacks using five Dynamic Global Vegetation Models (DGVMs). Glob. Change Biol. 2008, 14, 2015-2039. [CrossRef]

10. Yang, J.; Tian, H.; Pan, S.; Chen, G.; Zhang, B.; Dangal, S. Amazon drought and forest response: Largely reduced forest photosynthesis but slightly increased canopy greenness during the extreme drought of 2015/2016. Glob. Change Biol. 2018, 24, 1919-1934. [CrossRef]

11. Aragao, L.; Anderson, L.O.; Fonseca, M.G.; Rosan, T.M.; Vedovato, L.B.; Wagner, F.H.; Silva, C.V.J.; Silva Junior, C.H.L.; Arai, E.; Aguiar, A.P.; et al. 21st Century drought-related fires counteract the decline of Amazon deforestation carbon emissions. Nat. Commun. 2018, 9, 536. [CrossRef]

12. Yang, Y.; Saatchi, S.S.; Xu, L.; Yu, Y.; Choi, S.; Phillips, N.; Kennedy, R.; Keller, M.; Knyazikhin, Y.; Myneni, R.B. Post-drought decline of the Amazon carbon sink. Nat. Commun. 2018, 9, 3172. [CrossRef] [PubMed]

13. Masson-Delmotte, V.; Zhai, P.; Pirani, A.; Connors, S.L.; Péan, C.; Berger, S.; Caud, N.; Chen, Y.; Goldfarb, L.; Gomis, M.I.; et al. Summary for Policymakers. In Climate Change 2021: The Physical Science Basis. Contribution of Working Group I to the Sixth Assessment Report of the Intergovernmental Panel on Climate Change; Cambridge University Press: Cambridge, UK, 2021.

14. Nepstad, D.; Moutinho, P.; Dias-Filho, M.; Davidson, E.; Cardinot, G.; Markewitz, D.; Figueiredo, R.; Vianna, N.; Chambers, J.; Ray, D. The effects of partial throughfall exclusion on canopy processes, aboveground production, and biogeochemistry of an Amazon forest. J. Geophys. Res. Atmos. 2002, 107, LBA 53-1-LBA 53-18. [CrossRef]

15. Asner, G.P.; Alencar, A. Drought impacts on the Amazon forest: The remote sensing perspective. New Phytol. 2010, 187, 569-578. [CrossRef] [PubMed]

16. Lewis, S.L.; Brando, P.M.; Phillips, O.L.; van der Heijden, G.M.; Nepstad, D. The 2010 Amazon drought. Science 2011, $331,554$. [CrossRef] [PubMed]

17. Reiche, J.; Lucas, R.; Mitchell, A.L.; Verbesselt, J.; Hoekman, D.H.; Haarpaintner, J.; Kellndorfer, J.M.; Rosenqvist, A.; Lehmann, E.A.; Woodcock, C.E.; et al. Combining satellite data for better tropical forest monitoring. Nat. Clim. Change 2016, 6, 120-122. [CrossRef]

18. Baccini, A.; Walker, W.; Carvalho, L.; Farina, M.; Sulla-Menashe, D.; Houghton, R.A. Tropical forests are a net carbon source based on aboveground measurements of gain and loss. Science 2017, 358, 230-234. [CrossRef] [PubMed]

19. Saleska, S.R.; Didan, K.; Huete, A.R.; Da Rocha, H.R. Amazon Forests Green-Up During 2005 Drought. Science 2007, $318,612$. [CrossRef]

20. Brienen, R.J.; Phillips, O.L.; Feldpausch, T.R.; Gloor, E.; Baker, T.R.; Lloyd, J.; Lopez-Gonzalez, G.; Monteagudo-Mendoza, A.; Malhi, Y.; Lewis, S.L.; et al. Long-term decline of the Amazon carbon sink. Nature 2015, 519, 344-348. [CrossRef]

21. Saleska, S.R.; Wu, J.; Guan, K.; Araujo, A.C.; Huete, A.; Nobre, A.D.; Restrepo-Coupe, N. Dry-season greening of Amazon forests. Nature 2016, 531, E4-E5. [CrossRef] [PubMed]

22. Gatti, L.V.; Gloor, M.; Miller, J.B.; Doughty, C.E.; Malhi, Y.; Domingues, L.G.; Basso, L.S.; Martinewski, A.; Correia, C.S.; Borges, V.F.; et al. Drought sensitivity of Amazonian carbon balance revealed by atmospheric measurements. Nature 2014, 506, 76-80. [CrossRef]

23. Ju, J.; Roy, D.P. The availability of cloud-free Landsat ETM+ data over the conterminous United States and globally. Remote Sens. Environ. 2008, 112, 1196-1211. [CrossRef]

24. de Souza, E.G.; Scharf, P.C.; Sudduth, K.A. Sun Position and Cloud Effects on Reflectance and Vegetation Indices of Corn. Agron. J. 2010, 102, 734-744. [CrossRef]

25. Xu, M.; Jia, X.; Pickering, M.; Plaza, A.J. Cloud Removal Based on Sparse Representation via Multitemporal Dictionary Learning. IEEE Trans. Geosci. Remote Sens. 2016, 54, 2998-3006. [CrossRef]

26. Saatchi, S.S.; Harris, N.L.; Brown, S.; Lefsky, M.; Mitchard, E.T.; Salas, W.; Zutta, B.R.; Buermann, W.; Lewis, S.L.; Hagen, S.; et al. Benchmark map of forest carbon stocks in tropical regions across three continents. Proc. Natl. Acad. Sci. USA 2011, 108, 9899-9904. [CrossRef]

27. Esquivel-Muelbert, A.; Baker, T.R.; Dexter, K.G.; Lewis, S.L.; ter Steege, H.; Lopez-Gonzalez, G.; Monteagudo Mendoza, A.; Brienen, R.; Feldpausch, T.R.; Pitman, N.; et al. Seasonal drought limits tree species across the Neotropics. Ecography 2017, 40, 618-629. [CrossRef]

28. Schuur, E.A.G. Productivity and global climate revisited: The sensiticity of tropical forest growth to precipitation. Ecology 2003, 84, 1165-1170. [CrossRef]

29. Li, W.; Fu, R.; Juarez, R.I.; Fernandes, K. Observed change of the standardized precipitation index, its potential cause and implications to future climate change in the Amazon region. Philos. Trans. R. Soc. B Biol. Sci. 2008, 363, 1767-1772. [CrossRef]

30. Anderson, L.O.; Ribeiro Neto, G.; Cunha, A.P.; Fonseca, M.G.; Mendes de Moura, Y.; Dalagnol, R.; Wagner, F.H.; de Aragao, L. Vulnerability of Amazonian forests to repeated droughts. Philos. Trans. R. Soc. B Biol. Sci. 2018, 373, 20170411. [CrossRef] [PubMed] 
31. Zhang, L.; Xiao, J.; Zhou, Y.; Zheng, Y.; Li, J.; Xiao, H. Drought events and their effects on vegetation productivity in China. Ecosphere 2016, 7, e01591. [CrossRef]

32. Hua, T.; Wang, X.; Zhang, C.; Lang, L.; Li, H. Responses of Vegetation Activity to Drought in Northern China. Land Degrad. Dev. 2017, 28, 1913-1921. [CrossRef]

33. Fauset, S.; Baker, T.R.; Lewis, S.L.; Feldpausch, T.R.; Affum-Baffoe, K.; Foli, E.G.; Hamer, K.C.; Swaine, M.D. Drought-induced shifts in the floristic and functional composition of tropical forests in Ghana. Ecol. Lett. 2012, 15, 1120-1129. [CrossRef] [PubMed]

34. Guo, H.; Bao, A.; Ndayisaba, F.; Liu, T.; Jiapaer, G.; El-Tantawi, A.M.; De Maeyer, P. Space-time characterization of drought events and their impacts on vegetation in Central Asia. J. Hydrol. 2018, 564, 1165-1178. [CrossRef]

35. Aguirre-Gutiérrez, J.; Oliveras, I.; Rifai, S.; Fauset, S.; Adu-Bredu, S.; Affum-Baffoe, K.; Baker, T.R.; Feldpausch, T.R.; Gvozdevaite, A.; Hubau, W. Drier tropical forests are susceptible to functional changes in response to a long-term drought. Ecol. Lett. 2019, 22, 855-865. [CrossRef] [PubMed]

36. Zhang, Y.; Xiao, X.; Zhou, S.; Ciais, P.; McCarthy, H.; Luo, Y. Canopy and physiological controls of GPP during drought and heat wave. Geophys. Res. Lett. 2016, 43, 3325-3333. [CrossRef]

37. Rambal, S.; Lempereur, M.; Limousin, J.-M.; Martin-StPaul, N.; Ourcival, J.-M.; Rodriguez-Calcerrada, J. How drought severity constrains gross primary production (GPP) and its partitioning among carbon pools in a Quercus ilex coppice? Biogeosciences 2014, 11, 6855-6869. [CrossRef]

38. Yu, Z.; Wang, J.; Liu, S.; Rentch, J.S.; Sun, P.; Lu, C. Global gross primary productivity and water use efficiency changes under drought stress. Environ. Res. Lett. 2017, 12, 014016. [CrossRef]

39. Chen, S.; Huang, Y.; Wang, G. Detecting drought-induced GPP spatiotemporal variabilities with sun-induced chlorophyll fluorescence during the 2009/2010 droughts in China. Ecol. Indic. 2021, 121, 107092. [CrossRef]

40. Yang, J.; Song, X.; Zambrano, J.; Chen, Y.; Cao, M.; Deng, X.; Zhang, W.; Yang, X.; Zhang, G.; Tang, Y.; et al. Intraspecific variation in tree growth responses to neighbourhood composition and seasonal drought in a tropical forest. J. Ecol. 2020, 109, 26-37. [CrossRef]

41. Wang, S.; Wang, H.; Li, J.; Zhang, Z. Ants can exert a diverse effect on soil carbon and nitrogen pools in a Xishuangbanna tropical forest. Soil Biol. Biochem. 2017, 113, 45-52. [CrossRef]

42. Fei, X.; Song, Q.; Zhang, Y.; Liu, Y.; Sha, L.; Yu, G.; Zhang, L.; Duan, C.; Deng, Y.; Wu, C.; et al. Carbon exchanges and their responses to temperature and precipitation in forest ecosystems in Yunnan, Southwest China. Sci. Total Environ. 2018, 616-617, 824-840. [CrossRef] [PubMed]

43. Hua, Z. The tropical rainforest vegetation in xishuangbannan. Chin. Geogr. Sci. 1992, 2, 64-73.

44. Kalnay, E.; Kanamitsu, M.; Kistler, R.; Collins, W.; Deaven, D.; Gandin, L.; Iredell, M.; Saha, S.; White, G.; Woollen, J.; et al. The NCEP/NCAR 40-Year Reanalysis Project. Bull. Am. Meteorol. Soc. 1996, 77, 434-472. [CrossRef]

45. Harris, I.; Osborn, T.J.; Jones, P.; Lister, D. Version 4 of the CRU TS monthly high-resolution gridded multivariate climate dataset. Sci. Data 2020, 7, 109. [CrossRef] [PubMed]

46. McKee, T.B.; Doesken, N.J.; Kleist, J. The relationship of drought frequency and duration to time scales. In Proceedings of the Eighth Conference on Applied Climatology, Anaheim, CA, USA, 17-22 January 1993; pp. 179-183.

47. Brown, J.F.; Wardlow, B.D.; Tadesse, T.; Hayes, M.J.; Reed, B.C. The Vegetation Drought Response Index (VegDRI): A New Integrated Approach for Monitoring Drought Stress in Vegetation. GIScience Remote Sens. 2013, 45, 16-46. [CrossRef]

48. Guan, K.; Good, S.P.; Caylor, K.K.; Medvigy, D.; Pan, M.; Wood, E.F.; Sato, H.; Biasutti, M.; Chen, M.; Ahlström, A. Simulated sensitivity of African terrestrial ecosystem photosynthesis to rainfall frequency, intensity, and rainy season length. Environ. Res. Lett. 2018, 13, 025013. [CrossRef]

49. Sato, H. Simulation of the vegetation structure and function in a Malaysian tropical rain forest using the individual-based dynamic vegetation model SEIB-DGVM. For. Ecol. Manag. 2009, 257, 2277-2286. [CrossRef]

50. Huth, A.; Ditzer, T. Simulation of the growth of a lowland Dipterocarp rain forest with FORMIX3. Ecol. Modell. 2000, 134, 1-25. [CrossRef]

51. SEIB-DGVM. Available online: http:/ / seib-dgvm.com/ (accessed on 18 March 2021).

52. Horna, V.; Schuldt, B.; Brix, S.; Leuschner, C. Environment and tree size controlling stem sap flux in a perhumid tropical forest of Central Sulawesi, Indonesia. Ann. For. Sci. 2011, 68, 1027-1038. [CrossRef]

53. Senna, M.C.A. Fraction of photosynthetically active radiation absorbed by Amazon tropical forest: A comparison of field measurements, modeling, and remote sensing. J. Geophys. Res. 2005, 110, 1-8. [CrossRef]

54. Fei, X.H.; Song, Q.H.; Zhang, Y.P.; Yu, G.R.; Zhang, L.M.; Sha, L.Q.; Liu, Y.T.; Xu, K.; Chen, H.; Wu, C.S.; et al. Patterns and Controls of Light Use Efficiency in Four Contrasting Forest Ecosystems in Yunnan, Southwest China. J. Geophys. Res. Biogeosci. 2019, 124, 293-311. [CrossRef]

55. Liu, W.; Liu, W.; Li, P.; Duan, W.; Li, H. Dry season water uptake by two dominant canopy tree species in a tropical seasonal rainforest of Xishuangbanna, SW China. Agric. For. Meteorol. 2010, 150, 380-388. [CrossRef]

56. Song, Q.; Lin, H.; Zhang, Y.; Tan, Z.; Zhao, J.; Zhao, J.; Zhang, X.; Zhou, W.; Yu, L.; Yang, L.; et al. The effect of drought stress on self-organisation in a seasonal tropical rainforest. Ecol. Modell. 2013, 265, 136-139. [CrossRef]

57. Li, Z.; Zhang, Y.; Wang, S.; Yuan, G.; Yang, Y.; Cao, M. Evapotranspiration of a tropical rain forest in Xishuangbanna, southwest China. Hydrol. Processes 2010, 24, 2405-2416. [CrossRef] 
58. Liu, W.; Li, P.; Duan, W.; Liu, W. Dry-season water utilization by trees growing on thin karst soils in a seasonal tropical rainforest of Xishuangbanna, Southwest China. Ecohydrology 2014, 7, 927-935. [CrossRef]

59. Xu, Z.; Zhou, G.; Shimizu, H. Plant responses to drought and rewatering. Plant Signal. Behav. 2010, 5, 649-654.

60. Pook, E.W.; Costin, A.B.; Moore, C.W.E. Water stress in native vegeation during the drought of 1965. Aust. J. Bot. 1996, 14, $257-267$. [CrossRef]

61. Markewitz, D.; Devine, S.; Davidson, E.A.; Brando, P.; Nepstad, D.C. Soil moisture depletion under simulated drought in the Amazon: Impacts on deep root uptake. New Phytol. 2010, 187, 592-607. [CrossRef] [PubMed]

62. Baker, I.T.; Prihodko, L.; Denning, A.S.; Goulden, M.; Miller, S.; da Rocha, H.R. Seasonal drought stress in the Amazon: Reconciling models and observations. J. Geophys. Res. Biogeosci. 2008, 113, 1-10. [CrossRef]

63. Ivanov, V.Y.; Hutyra, L.R.; Wofsy, S.C.; Munger, J.W.; Saleska, S.R.; de Oliveira, R.C.; de Camargo, P.B. Root niche separation can explain avoidance of seasonal drought stress and vulnerability of overstory trees to extended drought in a mature Amazonian forest. Water Resour. Res. 2012, 48, 1-21. [CrossRef]

64. Rose, K.L.; Graham, R.C.; Parker, D.R. Water source utilization by Pinus jeffreyi and Arctostaphylos patula on thin soils over bedrock. Oecologia 2003, 134, 46-54. [CrossRef] [PubMed]

65. Drake, P.L.; Franks, P.J. Water resource partitioning, stem xylem hydraulic properties, and plant water use strategies in a seasonally dry riparian tropical rainforest. Oecologia 2003, 137, 321-329. [CrossRef] [PubMed]

66. Vicente-Serrano, S.M.; Gouveia, C.; Camarero, J.J.; Begueria, S.; Trigo, R.; Lopez-Moreno, J.I.; Azorin-Molina, C.; Pasho, E.; Lorenzo-Lacruz, J.; Revuelto, J.; et al. Response of vegetation to drought time-scales across global land biomes. Proc. Natl. Acad. Sci. USA 2013, 110, 52-57. [CrossRef]

67. Jones, H.G. Monitoring plant and soil water status: Established and novel methods revisited and their relevance to studies of drought tolerance. J. Exp. Bot. 2007, 58, 119-130. [CrossRef]

68. Chitra-Tarak, R.; Xu, C.; Aguilar, S.; Anderson-Teixeira, K.J.; Chambers, J.; Detto, M.; Faybishenko, B.; Fisher, R.A.; Knox, R.G.; Koven, C.D.; et al. Hydraulically-vulnerable trees survive on deep-water access during droughts in a tropical forest. New Phytol. 2021, 231, 1798-1813. [CrossRef]

69. Hummel, I.; Pantin, F.; Sulpice, R.; Piques, M.; Rolland, G.; Dauzat, M.; Christophe, A.; Pervent, M.; Bouteille, M.; Stitt, M.; et al. Arabidopsis plants acclimate to water deficit at low cost through changes of carbon usage: An integrated perspective using growth, metabolite, enzyme, and gene expression analysis. Plant Physiol. 2010, 154, 357-372. [CrossRef]

70. Tyree, M.T.; Cochard, H.; Cruiziat, P.; Sinclair, B.; Ameglio, T. Drought-induced leaf shedding in walnut: Evidence for vulnerability segmentation. Plant Cell Environ. 1993, 16, 879-882. [CrossRef]

71. Goulden, M.L.; Bales, R.C. California forest die-off linked to multi-year deep soil drying in 2012-2015 drought. Nat. Geosci. 2019, 12, 632-637. [CrossRef]

72. He, W.; Liu, H.; Qi, Y.; Liu, F.; Zhu, X. Patterns in nonstructural carbohydrate contents at the tree organ level in response to drought duration. Glob. Change Biol. 2020, 26, 3627-3638. [CrossRef]

73. Wu, X.; Liu, H.; Li, X.; Ciais, P.; Babst, F.; Guo, W.; Zhang, C.; Magliulo, V.; Pavelka, M.; Liu, S.; et al. Differentiating drought legacy effects on vegetation growth over the temperate Northern Hemisphere. Glob. Change Biol. 2018, 24, 504-516. [CrossRef]

74. Anderegg, W.R.; Anderegg, L.D.; Berry, J.A.; Field, C.B. Loss of whole-tree hydraulic conductance during severe drought and multi-year forest die-off. Oecologia 2014, 175, 11-23. [CrossRef] [PubMed]

75. McDowell, N.; Pockman, W.T.; Allen, C.D.; Breshears, D.D.; Cobb, N.; Kolb, T.; Plaut, J.; Sperry, J.; West, A.; Williams, D.G.; et al. Mechanisms of plant survival and mortality during drought: Why do some plants survive while others succumb to drought? New Phytol. 2008, 178, 719-739. [CrossRef] [PubMed]

76. Berg, A.; Sheffield, J. Climate Change and Drought: The Soil Moisture Perspective. Curr. Clim. Change Rep. $2018,4,180-191$. [CrossRef] 